\section{A NYUGDÍJBIZTOSÍTÁSOK SZEREPE ÉS JELLEMZÖI A KIEGÉSZÍTŐ NYUGDÍJPILLÉRBEN}

Dr. Barta Judit (Miskolci Egyetem Állam-és Jogtudományi Kar Civilisztikai Tudományok Intézete Kereskedelmi Jogi Tanszék tanszékvezetö egyetemi docens

\section{ÖSSZEFOGLALÓ}

Az állami nyugdíjat kiegészítő önkéntes előgondoskodás és ennek egyik lehetőségeként a nyugdíjbiztosítások szerepe mára vitathatatlanul fontossá vált. Az állam adókedvezménnyel és a szerződők érdekeit védő ajánlásokkal, szabályozással igyekszik ezen intézményt még vonzóbbá tenni. Fontos tudni ezért, hogy melyik életbiztosítás az, amely adókedvezményben részesül, mint nyugdíjbiztosítás, és milyen jogi szabályozás érvényesül a nyugdíjbiztosítási termékek vonatkozásában.

\section{SUMMARY}

The role of voluntary savings and the private insurances as a possibility of voluntary saving, which are supplementing the state pension, become clearly important nowadays. The state intends to make pension insurance more attractive by providing tax allowances, issuing recommendations and regulations, aiming the protection of the consumer For the above reasons it is important, to know, which life insurance is a subject of tax allowance, as pension insurance and what legal regulations are applicable for pension insurance products.

Kulcsszavak: társadalombiztosítási nyugdíj, kiegészítő nyugdíj, önkéntes előgondoskodás, életbiztosítás, adókedvezmény, unit-linked biztosítás, életjáradék

Keywords: social insurance, supplementary pension, voluntary savings, life insurances, tax allowance, unit-linked insurance, annuity

\section{JEL: K12, K39}

DOI: $10.18530 / B K .2018 .1 .42$

http://dx.doi.org/1018530/BK.2018.1.42

\section{A társadalombiztosítási nyugdíj}

Magyarországon 1975-ben jött lére a mindenkire kiterjedő, egységes társadalombiztosítás, a társadalombiztosításról szóló 1975. évi II. törvény elfogadásával. A piacgazdaságra való áttérés jelentősen megváltoztatta a társadalmi, gazdasági környezetet, új szabályokra volt szükség. 1997-ben három törvényt fogadtak el, melyek az új társadalombiztosítási szabályokat tartalmazták. Van egy átfogó, az általános alaptételeket lefektető törvény, továbbá van külön társadalombiztosítási nyugdíj (állami nyugdí) és külön kötelező egészségbiztosítási törvény.

A társadalombiztosítás rendszerében a biztosítottak kötelezően járulékot fizetnek. Cserébe jogot szereznek saját maguk és a törvényben meghatározott hozzátartozójuk javára az egyes társadalombiztosítási ellátásokra. Az állami nyugdíjrendszer felosztó-kirovó finanszírozási elven müködik. ${ }^{1}$ A társadalombiztosítási nyugdíjellátás lehet:

- öregségi nyugdíj és

hozzátartozói nyugellátás (özvegyi nyugdíj, árvaellátás, szülői nyugdíj, baleseti hozzátartozói nyugellátások), továbbá rehabilitációs járadék.

\section{A kiegészítő nyugdíj szerepe}

Magyarországon a magánszektornak kiegészítő szerepe van a nyugdíbbiztosítás területén. Feladata, hogy a társadalombiztosítási nyugdíjat kiegészítve magasabb megélhetési szintet biztosítson a nyugdíjas számára. ${ }^{2}$ Fontos rámutatni, hogy a felosztó-kirovó elven müködő társadalombiztosítási nyugdíjrendszerek a fejlett országokban megmutatkozó öregedő társadalom miatt komoly kihívásokkal néznek szembe ${ }^{3}$, ezekhez országonként egyéni hatások társulnak. Mindez igaz Magyarországra is. Az öregedő társadalom nyugdíjrendszerre gyakorolt hatásával több anyagában is foglalkozik az Európai Unió (Zöld Könyv, Fehér Könyv $\left.{ }^{4}\right)^{5}$, az OECD, valamint ezt a témát dolgozza fel számos irodalmi mű is, melyek közül az egyik legmegrendítőbb Frank Schirrmachernek „A Matuzsálem-összeesküvés” című könyve. ${ }^{6}$ Figyelemre méltó az is, hogy a legnagyobb világcégek állnak át olyan fejlesztésekre, amelyek az idős emberek igényeit szolgálják, látva azt, hogy ők hamarosan jelentős tényezői lesznek a fogyasztói társadalomnak. A Fehér Könyv elörevetíti, hogy a jövőben a kiegészitö nyugdij szerepe nem az lesz, hogy a keresöképes jövedelmi szintre egészitse ki az állami nyugdijat, hanem az, hogy a megélhetés szintjére egészitse ki azt.

\section{A magyar kiegészítő nyugdíjpillér alakulása}

A kiegészítő nyugdíjcélú megtakarításokat kínáló magánszektor, melynek a biztosítók által kínált nyugdíjbiztosítások is részei, a rendszerváltást követően kezdett kialakulni. Az első lépés az ún. önkéntes kölcsönös nyugdijpénztárak életre hívása volt 1993-ban.? Ezt követte a kötelező, tőkefedezeti elven működő, magánnyugdijpénztári rendszer kiépítése, amely egy bő évtizedig uralta a kiegészítő pillért. 
A kilencvenes évek közepén alakult úgy a gazdasági helyzet, hogy külső és belső okoktól vezérelve szükségessé vált a hazai nyugdíjrendszer átalakítása. A Világbank a felé fennálló tartozás visszafizetése érdekében és további hitelek nyújtása fejében elvárta a kapcsolódó reformok megindítását, és az ún. chilei modell mérsékeltebb változatának megvalósítását ösztönözte.

Magyarország a többi kelet-közép-európai országgal egyetemben - kivéve a nem eladósodott Szlovéniát és Csehországot - vezette be a kötelező kiegészitő tőkefedezeti rendszert 1997-ben. A magyar nyugdíjrendszer hárompilléres lett, a kötelező nyugdíjrendszer kétpilléres, az egyik pillér az állami felosztó-kirovó finanszírozású rendszer, a másik pedig a tőkefedezeti magánnyugdípénztári rendszer. A harmadik pillérbe az önkéntes nyugdij-előtakarékossági formák tartoztak. A 2003/41/EK irányelv kötelező átültetésének következményeként fogadták el Magyarországon a foglalkoztatói nyugdijról és intézményeiről szóló 2007. évi CXVII. törvényt, melynek alapján 2008-tól van lehetőség foglalkoztatói nyugdíjszolgáltató alapítására is. ${ }^{9}$

A magánpénztári tagok nyugdíjjárulék-alapot képező adóköteles jövedelmükből a munkáltató által kötelezően levont tagdijat fizettek a pénztárnak és nyugdijjárulékot az állami Nyugdíbiztositási Alapba. A nem magánpénztári tagok 8 százalék nyugdíjárulékot fizettek, míg a magánpénztári tagok csak 2 százalék járulékot és 6 százalék tagdijat, azaz a járulékuk nagyobbik része a magánpénztárhoz folyt be. Az állami Nyugdíjbiztosítási Alap bevétele a magánpénztári tagok tagdíjbefizetése miatt csökkent, az így kiesett nyugdíjárulékok hiányát az állami költségvetés terhére pótolták. Induláskor a tervezett kétszázezer emberhez képest ugyanakkor 3 millióan léptek át a vegyes rendszerbe, óriási hiányt okozva a nyugdijkasszában és ezzel a költségvetésben, amivel a döntéshozók eredetileg nem számoltak. Ennek az lett a következménye, hogy az államháztartási hiány meghaladta az Unió által megengedett mértéket. Az Európai Unió a csatlakozáskor ugyan adott haladékot a hiány leküzdésére, de amikor ez az idő eltelt, elutasította az áthidaló magyar javaslatokat, ezért a kormány lépéskényszerbe került. A helyzet megoldására adminisztratív eszközök alkalmazásával került sor, melynek során gyors, egymást követő törvénymódosításokkal avatkoztak be a tőkefedezeti magánnyugdíjrendszerbe. ${ }^{10}$ A magánnyugdíppénztári tagoknak választaniuk kellett: magánpénztári tagok maradnak, vagy visszalépnek a tisztán társadalombiztosítási nyugdíjrendszerbe. Aki nem lépett vissza, az 2011. december 1-jétől kezdődően a társadalombiztosítási nyugdíjrendszerben további szolgálati időt nem szerezhetett, ezzel elvesztette állami nyugdíjra való jogosultságát. Aki visszalépett, annak az addig befizetett tagdíját (valójában a be nem fizetett nyugdíjjárulékát és hozamait) átutalták egy külön erre a célra létrehozott állami alapba, viszont a tag saját vagy munkáltatója kiegészítő befizetését annak hozamával együtt visszakapta. ${ }^{11} \mathrm{~A}$ következő törvénycsomag enyhített ezeken a szabályokon, a pénztári tagságot választók visszakapták társadalombiztosítási várományukat, viszont megszüntették a magánnyugdíjpénztári rendszer kötelező jellegét, így a pénztárak önkéntesen választható kiegészítő nyugdíjszolgáltatókká váltak. A tagok önként, adózottjövedelmükből fizethetnek ún. hozzájárulást, amelynek mértékét nem a törvény, hanem a pénztár határozza meg. Magyarországon ezzel megszünt a kötelező előgondoskodás.

A kötelező tagság és a kötelező magánnyugdípénztári tagdíffizetés megszüntetése, továbbá a két lépcsőben is biztosított visszalépés a „tisztán” állami nyugdijrendszerbe, megtette a hatását, a magánnyugdijpénztári tagok létszáma drasztikusan lecsökkent, és csak néhány tőkefedezeti pénztár tudott fennmaradni a piacon. ${ }^{12} \mathrm{Ez}$ a helyzet új lehetőséget nyitott más piaci szereplők, így a biztosítók számára is, ugyanakkor bizonyos bizalomvesztés is bekövetkezett a kiegészítő nyugdíjcélú megtakarítási formák vonatkozásában. A bizalom helyreállítása érdekében különösen fontos a megfelelő tájékoztatás, amely alatt nemcsak a termék jellemzőit, kockázatait értjük, hanem utalást a makrokörnyezetre és akár a nemzetközi tendenciákra is

Rendszerszinten a magyar nyugdíjrendszer kétpilléres lett; az első pillér az állami nyugdíjrendszer, a második pillér pedig az önkéntes, kiegészítő pillér, amelybe valamennyi intézményes nyugdij-előtakarékossági forma beletartozik, mint a tőkefedezeti magánnyugdíjpénztárak, önkéntes kölcsönös nyugdíjpénztárak, foglalkoztatói nyugdíj, az ún. adótámogatott nyugdí-előtakarékossági számla (NYESZ), valamint a nyugdíjbiztosítások.

\section{A nyugdíjbiztosítási szerződések jellemzői, különös szabályai}

A nyugdíjbiztosítás egy olyan életbiztosítás, ahol a cél a nyugdíjas évekre történő előgondoskodás. Ez - a befizetés nagyságától függően - minimum 10, de inkább 20 év vagy e fölötti fenntartást igényel. Ez alatt az időszak alatt a biztosított életében számtalan fordulat állhat be, emiatt érdemes az elérési jelleget a biztosítók által kínált kockázati elemekkel (pl. halál, egészségkárosodás) kombinálni.

A befizetett összeg befektetésre kerül, annak érdekében, hogy hozamából minimum fedezhető legyen a biztosító szolgáltatásának díja (költség) és a reálérték megtartása. $A$ nyugdijbiztositásokra az életbiztositásokra vonatkozó szabályozás az irányadó, az alább hivatkozott különös szabályokon túl.

\section{A 2014-ben bevezetett állami támogatás nem mindegyik nyugdíjcélú biztosításhoz jár, csak a Szja. tv. által meghatározott jellemzőkkel rendelkező biztosításokhoz.}

A nyugdíjcélú életbiztosítások száma az utóbbi időben gyarapodott, ennek egyik oka, hogy 2014-től az állam adótámogatással ösztönzi e szerződések kötését. ${ }^{13}$

Az állami adótámogatás ténylegesen adókedvezmény. Ez azt jelenti, hogy az előgondoskodó által megfizetett személyi jövedelemadó 20 százalékát, de legfeljebb a törvény által meghatározott összeget ${ }^{14}$ az állami adóhivatal a szolgáltatást nyújtó intézménynek átutalja.

A 2014-ben bevezetett állami támogatás azonban nem mindegyik nyugdíjcélú biztosításhoz jár, csak a személyi jövedelemadóról szóló 1995. törvény (Szja. tv.) által meghatározott jellemzőkkel rendelkező biztosításokhoz. ${ }^{15}$ A Szja tv. 3.\$93. pont szerint nyugdíjbiztosításnak minősül az az életbiztosítási szerződés, ahol a biztosító teljesítésére - a haláleseti szolgáltatást kivéve - a nyugdíjbiztosítási szerződés egész tartama alatt a biztosított jogosult, és a biztosítói teljesítést a biztosított 
a) halála,

b) saját jogú nyugellátásra való jogosultságának megszerzése (nyugdíjba vonulás),

c) legalább 40 százalékos mértéket elérő egészségkárosodása, kivéve, ha ez szerződéskötéskor is fennállt már (függetlenül attól, hogy rokkantsági vagy rehabilitációs ellátásra jogosult-e vagy sem), vagy

d) a szerződés létrejöttekor érvényes öregségi nyugdijkorhatár biztosított általi betöltése váltja $\mathrm{ki}^{16}$, feltéve, hogy a nyugdíjbiztosítási szerződés létrejöttétől a biztosító biztosítási eseményre tekintettel történő teljesítéséig (bizonyos törvényi kivételektől eltekintve) legalább 10 év eltelik, és az a)-d) pontokban szereplő biztosítási eseményeken kívül más biztosítási eseményt nem tartalmaz.

A Szja tv. leírt rendelkezései szerint a nyugdíjbiztosításnak négy biztosítási eseménye van, amelyekből valójában a tényleges nyugdíjba vonulás, illetve az öregségi nyugdíjkorhatár betöltése tekinthető nyugdijbiztosítási célnak. A törvény szerint az adókedvezmény igénybevételére az öregségi nyugdijkorhatár betöltése után már nincs lehetőség. A nyugdíjbiztosítás adójogi szempontú ismérveinek definiálásával nem született új életbiztosítási kategória, mindössze a jogalkotó kifejezte, hogy nem minden nyugdíjcélú életbiztosítást kíván kedvezményben részesíteni.

A támogatás további feltétele, hogy a szerződő személyi jövedelemadót fizessen. Az adókedvezmény a megfizetett személyi jövedelemadóhoz füződik, valójában a megfizetett adó egy részéről való rendelkezési jogot jelent, annak megszolgált összegét, de maximum a törvényben meghatározott mértéket minden év végén az adóhivatal átutalja a biztosítóhoz, aki azt jóváírja a biztosított egyéni számláján.

Tudható volt, hogy az adókedvezmény lendületet ad a nyugdíjbiztosítási piacnak, miközben ezt különféle vádak érték, például, hogy a termékek drágák, mert a közvetítők biztosítási díjba beépített jutaléka magas, a termékek költsége nem átlátható, a termékek nem értékállók, stb.

Mindezek okán a Magyar Nemzeti Bank (MNB) ajánlást adott ki 2/2014. (V. 26.) számmal a nyugdíjbiztosítási termékekre és közvetítésükre vonatkozóan, amely a legfontosabb területeken fogalmazta meg elvárásait.

Az egyik, hogy a szerzödések egyszerü szerkezetüek, átláthatók - különösen a konstrukció és a költségek tekintetében - és értékállók legyenek, azaz valóban szolgálják az önkéntes elögondoskodást. A termék szerkezetét úgy kell felépíteni, hogy a termék dijának befektetéséből származó eredmény legalább a biztosító felszámított költségeit és az inflációt fedezze komoly eséllyel, és az adókedvezmény ezen felül, tényleges előnyként jelentkezzen. Elvárás, hogy a termékekhez kötődő adókedvezmény a szerződő nyugdíjcélú megtakarításait gyarapítsa, ne a biztosítóhoz kerüljön. A biztosítók kínálhatnak tőkegaranciát, illetve hozamgaranciát, amellyel a befizetett összegek megtartását, illetve az előre ígért hozamot is garantálják.

Az ún. unit-linked nyugdíjbiztosítások ${ }^{17}$ esetében, ahol a szerződő viseli a befektetés kockázatát, további követelmények is megjelennek. Itt elvárható, hogy a biztosító kínáljon az ügyfél korát figyelembe vevő befektetési lehetőségeket, azaz közelítve a nyugdíjas kor felé, egyre kisebb kockázatú, ún. konzervatív befektetési lehetőséget is biztosítson, ami csökkenti a felhalmozott nyugdíjmegtakarítás elvesztésének veszélyét. Különösen hangsúlyos a megfelelő tájékoztatás: a szerződő számára világosan ki kell derülnie, hogy mekkora és milyen befektetési kockázat hárul rá.

A MNB az ún. teljes költségmutató (TKM) ${ }^{18}$ vonatkozásában is megfogalmazta elvárásait, 10 éves lejáratnál legföljebb 4,25 százalék, 15 évesnél 3,95 százalék, 20 éves futamidőnél pedig 3,5 százalékot tart elfogadhatónak a nyugdíjbiztosításoknál. Kivételes esetben enged maximum 1,5 százalékkal magasabb TKM-t, az eltérés okait pedig számszerü módon ki kell mutatni, és meg kell indokolni a szerződő felé.

Mivel a nyugdíjmegtakarítás célja lehet a rendszeres, élethosszig tartó jövedelemkiegészítés biztosítása, elvárható, hogy a termékek járadékszolgáltatást - lehetőleg többfélét -, köztük életjáradékot is tartalmazzanak. A járadékszolgáltatás nyújtását illetően a Szja. tv. és az MNB ajánlása tartalmaz előírásokat.

Fontos elvárás, hogy a nyugdíjbiztosításokat megfelelő szakismerettel rendelkező közvetítők „árusítsák”, akik - a szerződők igényeinek helyes felmérése után - képesek megfelelő terméket ajánlani. Alapos befektetési ismeretek, tapasztalatok nélkül nem szabad unit-linked terméket választani, illetve ajánlani.

További MNB-ajánlás, hogy a nyugdíjbiztosítások esetében a biztosítók a jutalékokat „csepegtessék”, azaz ne egy összegben és a szerződés megkötésekor fizessék ki a jutalékot, hanem azt elosztva a tartam alatt, ezzel a közvetítőt érdekeltté téve a szerződések hosszú távú fenntartásában.

A nyugdíjbiztosítás - összehasonlítva az egyéb kiegészítő nyugdíjcélú megtakarítási formákkal - több előnnyel is rendelkezik. Ilyen például az, hogy tartalmaz kötelező kockázati elemet (egészségkárosodás, halál).

Halál bekövetkezése esetén meghatározott biztosítási összeg kerül kifizetésre a kedvezményezett részére, amely összeg a szerződéskötést követő rövid időn belüli biztosítási esemény bekövetkezése esetén meghaladja az addigi befizetéseket. Más nyugdíjcélú megtakarítási formáknál csak az egyéni számlán felhalmozott megtakarítás örökölhető, rövid időn belül bekövetkező halál esetén ez kedvezőtlen. A járadékos időszakban történő elhalálozás esetén egyik intézménynél sincs örökölhetőség, ennek oka, hogy a járadékosok kockázatközösséget alkotnak, és azok számára, akik a számított átlagéletkorhoz képest tovább élnek, átcsoportosítják az elhaltak megtakarítását. A NYESZ nem nyújt járadékszolgáltatást, itt csak örökölhetőség van. ${ }^{19} \mathrm{Az}$ egészségkárosodás kockázatát csak a biztosítási termékek - értelemszerűen pluszdíj ellenében - tudják biztosítani.

Előny, hogy a szerződő a biztosítás díját fizetheti egy összegben, illetve teljesítheti rendszeres befizetésekkel, sőt, rendkívüli befizetésekre is van lehetőség. A szerződő döntheti el, hogy az aktív befektetési közreműködést igénylő és befektetési kockázattal is párosuló unit-linked szerződést köt, vagy olyan, garanciát is magában foglaló terméket választ, ahol a befektetési kockázatot a biztosító viseli. A nyugdíjbiztosítás tehát azoknak is alkalmas megoldás, akik nem rendelkeznek befektetési ismeretekkel és tapasztalatokkal. 
A fenti jellemzőket és az adókedvezményt figyelembe véve, a nyugdíjbiztosítás az egyik legrugalmasabb előgondoskodási megoldás, emellett igen hatékony (értve ezalatt a költségeket és az elérhető hozamot) is lehet. ${ }^{20}$

Összegzésként elmondható, hogy a negyvenéves, de még az ötvenéves korosztálynál is érdemes, sőt indokolt az önkéntes előgondoskodás a nyugdíjas évekről. Az állami adótámogatás is erre ösztönöz. A rendelkezésre álló kiegészítő nyugdíjcélú megtakarítási formák közül célszerű mindenkinek azt a megoldást választania, amely legjobban illeszkedik a megtakarítási szokásaihoz, kockázati profiljához és a befektetői aktivitásához.

\section{HIVATKOZÁSOK}

'Folyó bevételekből, azaz járulékokból fedezi a folyó kiadásokat, azaz a nyugdijakat. A felosztó-kirovó elven működő nyugdijirendszerrőll és az azt érintő reformtörekvésekró̉ ír bővebben Vallasek Magdolna, összehasonlítva a román és magyar nyugdijrendszert. Vallasek Magdolna (2014): Gondolatok egy reformkoncepcióról - gyermekneveléstöl függó nyugdij? https://www.nyugat.ro/?p=109

65-74 éves nyugdijasok nyugdiját viszonyítva az 50-59 évesek keresetéhez, az állapítható meg, hogy a nyugdíj mértéke

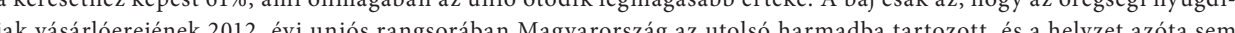

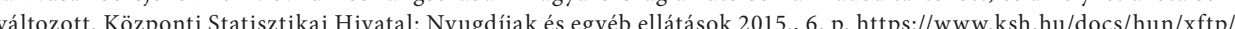
idoszaki/regiok/orsz/nyugdij/nyugdij15.pdf

${ }^{3}$ A születések alacsony száma mellett, a várható élettartam hosszabbodása következtében az időskorúak (65 év felettiek) száma és aránya növekszik a társadalmon belül. Finanzzirozási probléma a felosztó-kirovó rendszerekben: csökken a járulékfizetők száma, de növekednek a nyugdíkiadások.

„„Európa szociális és gazdasági sikere szempontjából a nyugdijkérdés kiemelkedően fontossá vált, egyre inkább közös uniós probléma."

Az Európai Bizottság által 2010-ben kidolgozott „A megfelelő, fenntartható és biztonságos európai nyugdijirendszerek felé” címü Zöld Könyv, és a 2012-ben elfogadott „A megfelelö, biztonságos és fenntartható európai nyugdíak menetrendje" címủ Fehér Könyv

"Frank Schirrmacher (2007): A Matuzsálem-összeesküvés. Scolar Kiadó, Budapest. Az eredeti mű 2004-ben jelent me `Az önkéntes kölcsönös biztosító pénztárakról szóló 1993. évi XCVI. törvény

${ }^{\circledR}$ A tókefedezeti elv lényege, hogy a magánnyugdíppénztári tagok havonta történő befizetéseit a pénztár tartalékolja és befekteti az ún. felhalmozási időszzak vagy várakozási idő alatt (törvény által meghatározott időtartama minimum 15 ev), ezzelterenti meg

a Bővebben Barta Judit (2011): Visszatérés az egypilléres kötelezö nyugdírendszerhez (a 2010. december 13-án elfogadott törvényco 2011. február elején közzétett adatok szerint a magánpénztártagok 98 százaláka visszalépett az állami nyugdíirendszerbe. ${ }^{12} \mathrm{~A}$ magánnyugdíjpénztárak 3 milliót meghaladó taglétszáma 2011. végére 99.299 före, 2012. március végére 74.400 före apadt. 2014-re négy tőkefedezeti magánnyugdijpénztár maradt, körülbelül 61 ezer taggal, 2016-ban már 58 ezer főnél is kevesebb tag volt

${ }^{13}$ A 2016-os biztositoi adatok tükrében a nyugdíicélú öngondoskodási formák között a nyugdíbiztositás a legdinamikusabban fejlodo megtakaritas, koszonhetoen az adokedvezmenynek is. Forrás: http://www.biztositasiszemle.hu/cikk/ hazaihirek/eletbiztositas/csak_minden_otodik_magyar_takarekoskodik_a_nyugdijas_eveire.5629.htm "Önkéntes kölcsönös nyugdíjpénztári megtakarítás esetén ez $150.000 \mathrm{Ft}$, NYESZ esetén $100.000 \mathrm{Ft}$, nyugdíbiztosítás
esetén $130.000 \mathrm{Ft}$.

Magyar Biztositók Szövetsége által közzétett adatok szerint az adókedvezménynek köszönhetően, jelentősen megnövekedett a nyugdíjbiztosítások száma. 2016 első negyedévében számuk elérte a 175 ezret, a szerződésekre befizetett dijbevétel pedig meghaladta a 37,I milliárd forintot. Forrás: http://www.mabisz.hu/images/stories/docs/sajto/mabiszsajtotajekoztato20151222.pd

"Az 195\%. január 1-jetor szalletett szennelyek számára 65 év az öregségi nyugdijkorhatár.

${ }^{17 A z ~ e ́ l e t b i z t o s i t a ́ s i ~ p i a c o n, ~ e z e n ~ b e l u ̈ l ~ a ~ n y u g d i j b i z t o s i t a ́ s o k ~ k o ̈ r e ́ b e n ~ i s, ~ n a g y o b b ~ a r a ́ n y b a n ~ k o ̈ t n e k ~ u n i t-l i n k e d ~ b i z t o s i ́ t a ́ s o k a t . ~}$ ${ }^{18} \mathrm{~A}$ Bit. 4. \$ (1) bekezdés 97. pont szerint, teljes költségmutató (TKM): a megtakarítási életbiztositási termékekre számolt olyan mutató, amely egy értékben összegzi a szerződéssel kapcsolatban felmerült valamennyi költséget." ${ }^{1 \mathrm{~A}} 2011$. február elején kozzzétett ady nyugdijpillé egyes ineér.

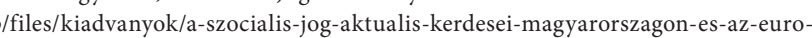
pai-unioban.pdf, vagy Friedrich Ebert Stiftung

http://fesbp.hu/common/pdf/A_szocialis_jog_aktualis_kerdesei_2017.pdf

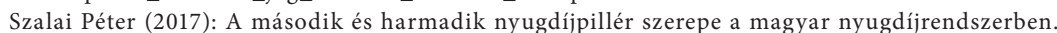
Pénzügyi Szemle, 2. sz.., pp. 214-233.

https://www.penzugyiszemle.hu/documents/pandurics-szalai-2017-2-mpdf_20170717152417_4.pdf

\section{IRODALOMJEGYZÉK}

Barta Judit (2011): Visszatérés az egypilléres kötelezô nyugdijirendszerhez (a 2010. december 13-án elfogadott törvénycsomag értékelése), Gazdaság és Jog, XIX. évf., 3. szám, pp. 9-15.

Barta Judit (2016): Örökölhetőség, és hozzátartozói ellátás kérdése a magyar kiegészitő nyugdijipillér egyes intézményeiben, Mélypataki Gábor (szerk.): A szociális jog aktuális kérdései Magyarorszzágon és az Európai Unióban. Konferenciakötet, Miskolci Egyetem, Alllam- és Jogtudományi Kar
Ear

http://jogikar.u

vagy Friedrich Ebert Stiftun

http://fesbp.hu/common/pdf/A_szocialis_jog_aktualis_kerdesei_2017.pd

Frank Schirrmacher (2007): A Matuzsálem-összeesküvés, Scolar Kiadó, Budapest

Pandurics Anett - Szalai Péter (2017): A második és harmadik nyugdíjpillér szerepe a magyar nyugdijirendszerben, Pénzügyi Szemle, 2. sz., pp. 214-233.

Vallasek Magdolna (2014): Gondolatok egy reformkoncepcióról - gyermekneveléstől függő nyugdí? https://www.nyugat.ro/?p=109

Letöltve 2018.01.31.

Az Európai Bizottságáltal 2010-ben kidolgozott „A megfelelő, fenntartható és biztonságos európai nyugdijirendszerek felę” címü Zöld

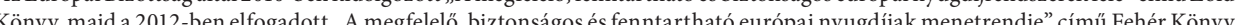

Központi Statisztikai Hivatal: Nyugdíjak és egyéb ellátások 2015.

https://www.ksh.hu/docs/hun/xftp/idoszaki/regiok/orsz/nyugdi//nyugdij15.pdf Letöltve 2018.01.31 